\title{
INVESTIGATION OF THE LASER ENGRAVING OF AISI 304 STAINLESS STEEL USING A RESPONSE-SURFACE METHODOLOGY
}

\author{
Vladan Mladenovič, Peter Panjan, Srečko Paskvale, Halil Çalişsan, Nastja Poljanšek, Miha Čekada
}

Original scientific paper In this paper we present the laser-beam engraving of a cold-rolled AISI 304 stainless-steel plate used for intaglio printing (e.g., banknotes and passports). This intaglio printing process allows the ink from a desired engraved pattern (e.g., microletters and images) to be transferred to a sheet of paper. The intensity of the colour and the ability to prevent the forgery of raised characters that appear on the paper correspond to the channel geometries formed by the laser-beam engraving. In order to obtain the appropriate channel geometry, and to avoid time-consuming, trial-and-error experiments, the engraving parameters must be optimized. For this purpose the Design of Experiments method and the orthogonal array $\mathrm{L}_{27}\left(3^{4}\right)$ were selected. A statistical analysis ANOVA at the $95 \%$ confidence level was performed using the statistical software. It was found that the scan speed is the most significant factor affecting the groove geometry.

Keywords: AISI 304 stainless-steel; analysis of variance; design of experiments; laser-beam engraving; response surface methodology

\section{Istraživanje laserskog graviranja nehrđajućeg čelika AISI 304 primjenom metodologije odzivne površine (RSM)}

Izvorni znanstveni članak U ovom članku predstavljen je proces laserskog graviranja, hladno valjanog nehrđajućeg čelika AISI 304, primjenom tehnike za tiskanje - intaglio tiska (npr. novčanice i putovnice). Proces intaglio tiska omogućava da se tinta iz željenog graviranog uzorka (npr. mikroslova i slike) prenosi na list papira. Intenzitet boje ispupčenih likova koji se pojavljuju na papiru onemogućavaju krivotvorenje i odgovaraju geometriji kanala koji nastaju tijekom laserskog graviranja. Da bi se dobila odgovarajuća geometrija kanala, i da bi se izbjegli dugotrajni eksperimentalni pokušaji i pogreške, parametri graviranja moraju biti optimirani. U tu svrhu primijenjena je metoda plana eksperimenta (DoE), koristeći ortogonalni plan $\mathrm{L}_{27}\left(3^{4}\right)$. Analiza varijance (ANOVA) izvedena je na razini $95 \%$ povjerenju, koristeći statistički softver. Utvrđeno je, da je brzina skeniranja najznačajniji ulazni parametar laserskog graviranja koji utječe na geometriju kanala.

Ključne riječi: analiza varijance; eksperimentalni plan (DoE); lasersko graviranje; metodologije odzivne površine (RSM); nehrđajući čelik AISI 304

\section{Introduction}

In the intaglio printing process the ink is applied directly to the engraved plate, after which it is transferred to the paper sheet. Using this process, an intaglio printing sheet can have tactile security images. Creating the intaglio plate with an engraved pattern is a very important task in the industrial production of security printings (e.g., banknotes, passports and visas). The desired pattern (e.g., microletters, lines and images) can be achieved by laser ablation $[1,2]$. The intensity of the colour on the paper corresponds to the engraved channel geometry. Deeper or larger channels will produce more-intense colours while smaller channels will produce less-intense ones. This means that the geometry of the channels must be carefully determined.

Laser engraving (also known as laser micromilling or laser ablation) is a thermo-mechanical process where the laser-beam energy is used for the removal of the workpiece material [3]. This method is particularly appropriate for machining hard materials that are difficult to machine by conventional means $[4,5]$. The high-power laser density is released within a short time interval (pulse duration) onto a target spot that is a few micrometres in diameter and can reliably produce high-resolution images onto various metal (e.g., copper and stainless steel) [6] The laser-beam influences the surface in various ways, depending on the process parameters and the material being used $[7 \div 9$ ]. When using a metal, a part of the laserbeam's energy is reflected, while the rest of the energy is transformed into heat (Fig. 1a). The amount of heat increases with the laser-beam's pulse duration. The surface temperature rapidly increases, possibly up to the melting point (Fig. 1b), or even to the boiling point, where the material is removed from the target area as vapour (Fig. 1c). With sufficiently high energy the high pressure emerges and the plasma appears (Fig. 1d). The plasma leads to an additional non-linearity in the laserablation process $[10,11]$.

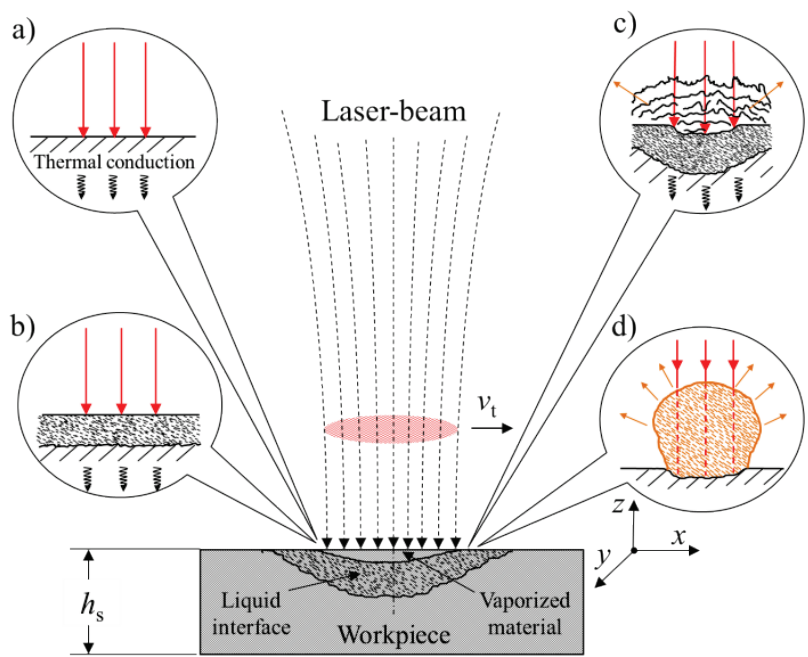

Figure 1 Schematic of the laser-beam irradiated material; heating (a), melting (b), vaporization and melting (c) and plasma formation (d)

In recent years, several experiments involving laserbeam engraving have been reported, discussing different processing conditions. In these studies, $\mathrm{CO}_{2}, \mathrm{Nd}$ :YAG and, in recent years, fibre lasers have mostly been used $[8,12]$. Dobrev et al. [14] investigated crater formation on a stainless-steel AISI 316 target, using a Nd:YAG laser- 
ablation system, for a single laser pulse of $10 \mu$ s and operating with various laser fluencies from $0,0286 \mathrm{~J} / \mathrm{mm}^{2}$ to $2,86 \mathrm{~J} / \mathrm{mm}^{2}$. They found the temperature of the target spot increased (above $3173 \mathrm{~K}$ ) along the material's depth (up to $50 \mu \mathrm{m}$ ). The width of the remelted zone on the workpiece was determined by the effective laser-beam diameter. This diameter varied between 1,7 and 2,0 mm [11]. Saklakoglu and Kasman [12] investigated the influences of the laser-engraving process parameters on the surface roughness and the groove depth, using AISI H13 hot-working steel and a $30-\mathrm{W}$ fibre laser source. They used a regression analysis to develop a mathematical model and determined the effect of the process parameters for both responses. Their study showed that the lowest pulse frequency $(20 \mathrm{kHz})$, the lowest laser power $(18 \mathrm{~W})$, the overlapping distance $(30 \mu \mathrm{m})($ peak-to-peak distance of the laser-beam) and the highest scan speed $(800 \mathrm{~mm} / \mathrm{s})$ produced the lowest surface roughness. The maximum groove depth was achieved at the maximum pulse frequency $(40 \mathrm{kHz})$, while the power, the scan speed and the overlapping distance were set to the minimum experimental values.

As was already mentioned, the engraving of stainless steel is an important feature of the security-printing field. The geometry of the engraving channels must be carefully determined in order to achieve intaglio printing of high quality. The customer usually predefines the security figures with an appropriate tactile geometry, such as the depth, height and width. These parameters are particularly important for determining the quality of the print. The determination of the proper engraving parameters is a time-consuming procedure where a lot of different combinations of engraving parameters have to be considered.

The literature related to the modelling and optimization of laser engraving often uses the statistical Design of Experiment (DoE) and orthogonal arrays, developed by Taguchi, and the Response-Surface Methodology (RSM), which is used to obtain the optimum results $[8,15 \div 18]$. This paper follows the same principle. The tests for the significance of the regression and the individual model coefficients were performed to prove the fitting to the obtained model. The analysis of variance (ANOVA) was applied to summarize the tests performed. ANOVA essentially consists of partitioning the total variation in an experiment into components that can be ascribed to the controlled factors and errors $[9,12]$. The main aim of using RSM and ANOVA is to detect the effect of each factor and their interactions on the responses, and to explain the effect as a numerical value using a mathematical model of the experiments. The results of the ANOVA contain:

- $\quad F$ value (the mean square error to residual),

$p$-value (the significance level),

correlation coefficient $R^{2}$,

adjusted correlation coefficient $R_{\text {adj }}^{2}$

predicted correlation coefficient $R_{\text {pred }}^{2}$,

signal-to-noise ratio $(S / N)$.

When the $p$-values are less than $0,05(p$-value $<0,05)$, the obtained models are considered to be statistically significant (or at the $95 \%$ confidence level). If the $p$ values are less than $0,0001(p$-value $<0,0001)$, then the model demonstrates that the chosen terms in the model have a primary significant effect on the responses. The $R^{2}$ value is a measure of the amount of variation around the mean explained by the model. The more $R^{2}$ approaches a value of unity, the better the response model fits the actual data. $R_{\text {adj }}^{2}$ is the adjusted value of $R^{2}$ for the number of terms in the model. $R_{\text {adj }}^{2}$ decreases as the number of terms in the model increases if those additional terms do not add value to the model. $R_{\text {pred }}^{2}$ is a measure of the amount of variation in the new data explained by the model.

The values of $R^{2}, R_{\text {pred }}^{2}$ and $R_{\text {adj }}^{2}$ should be as close as possible to each other, and close to $1(100 \%)$. The signalto-noise ratio $(S / N)$ compares the range of the predicted values at a design point with the average prediction error. Ratios greater than 4 indicate an adequate model discrimination.

Detailed explanations of the ANOVA values are given in the Design Expert 8 software [19], which was used for this investigation of the engraved surface properties. Design Expert provides a highly efficient DoE and enables higher-degree polynomial models.

\section{Experimental}

For the experimental work, cold-rolled austenitic stainless steel AISI 304 was chosen (Ni 8,02\%, Cr $18,11 \%, \quad$ C $0,037 \%, \quad$ Si $0,35 \%, \quad$ Mn $1,28 \%$, $\mathrm{S} 0,005 \%$, P $0,031 \%$ and $\mathrm{N} 0,053 \%$ weight, with $\mathrm{Fe}$ being the balance). The thickness of the workpiece was $0,8 \mathrm{~mm}$ and the hardness was $170 \pm 10 \mathrm{HV}$.

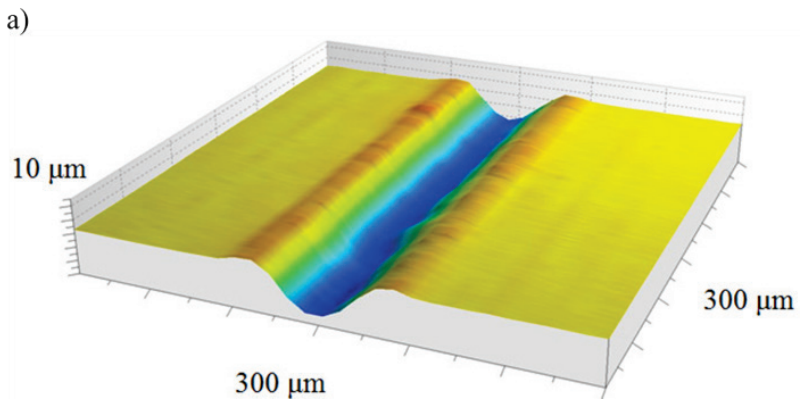

b)

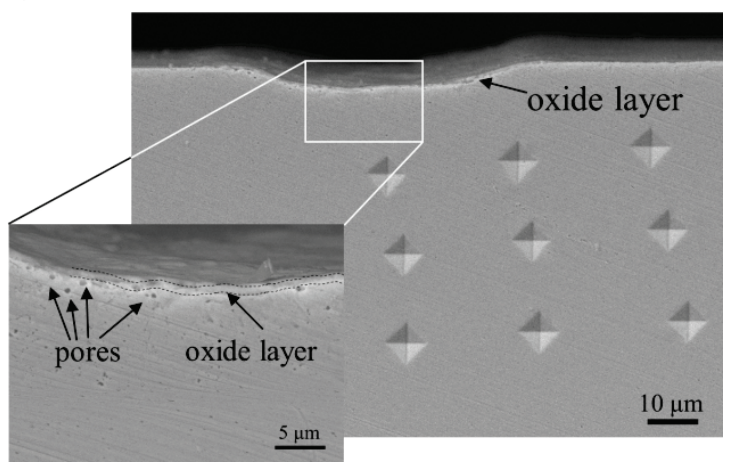

Figure 2 3D-topography of a typical laser-engraved contour (a) and SEM image at the cross-section and the small marks of the hardnessmeasurement indentations (b)

Engraving experiments were designed with the computer program Visual LaserMarker (Rofin). The 300FL (Gravograph) fibre-laser engraving machine was used with a maximum average laser power of $30 \mathrm{~W}$ and a wavelength of $1064 \mathrm{~nm}$. The processing laser-beam has a 
nearly Gaussian transverse mode structure (beam quality parameter $M^{2}$ of $\left.1,2 \div 1,8\right)$, divergence of the laser-beam $0,3 \mathrm{mrad}$, focused to a diameter of $\sim 20 \mu \mathrm{m}$ on the workpiece surface with a $224 \mathrm{~mm}$ focal distance and a pulse duration of $90 \div 120 \mathrm{~ns}$. The position of the laserbeam's focus can be adjusted along the $z$ direction. The size of the scanning area of the laser system is $100 \times 100 \mathrm{~mm}^{2}$. A special clamping arrangement was made to hold the workpiece. A sufficiently long groove was made for each parameter combination.

The groove topography was measured using a profilometer (Taylor Hobson Talysurf Series 2) and a confocal optical microscope (Zeiss Axio CSM 700). In the cross-section the microstructure was evaluated using a field-emission SEM (Jeol JSM-7600F). A typical 3Dprofilometer image of the groove is shown in Fig. 2a and a typical SEM image at the cross-section in Fig. $2 b$.

The engraving tests were performed at a constant environmental temperature at $21^{\circ} \mathrm{C}$ in standard atmospheric conditions. The engraving parameters were selected based on the available literature data $[9,10,16]$, our experience, the laser manufacturer's recommendation and our preliminary tests.

In this study the $\mathrm{L}_{27}$ Taguchi standard orthogonal array was used for the experimental design. Based on this DoE, a set of 27 experiments was performed [20]. The experiments were conducted using four process parameters (called factors) at three discrete values (called levels), as listed in Tab. 1. The factors for the statistical analysis are: pulse frequency $\left(f_{\mathrm{p}}\right)$, average output laser power $(P)$, laser-beam scan speed $\left(v_{t}\right)$ and laser-beam focus $(z)$. In this study quadratic interactions were applied. The ANOVA was performed to investigate which factors significantly affect the performance characteristics.

Table 1 Laser-engraving parameters and their levels

\begin{tabular}{|l|c|c|c|}
\hline & \multicolumn{3}{|c|}{ Level } \\
\hline Engraving parameter (factor) & low & medium & high \\
\hline Pulse frequency, $f_{\mathrm{p}}(\mathrm{kHz})$ & 50 & 100 & 150 \\
\hline Power, $P(\mathrm{~W})$ & 10 & 12 & 15 \\
\hline Scan speed, $v_{\mathrm{t}}(\mathrm{mm} / \mathrm{s})$ & 5 & 15 & 30 \\
\hline Focus, $z(\mathrm{~mm})$ & 0 & 1 & 2 \\
\hline
\end{tabular}

We investigated the following geometrical response variables: groove cross-section area $\left(A_{\mathrm{g}}\right)$, groove depth $\left(h_{\mathrm{g}}\right)$ and groove width at zero plane $\left(w_{0}\right)$. They are schematically shown in Fig. 3. They were calculated from a series of parallel line profiles measured across the groove, using the profilometer. An average of 30 profiles was taken. The medium line was interpolated between the undisturbed surfaces on both sides of the groove.

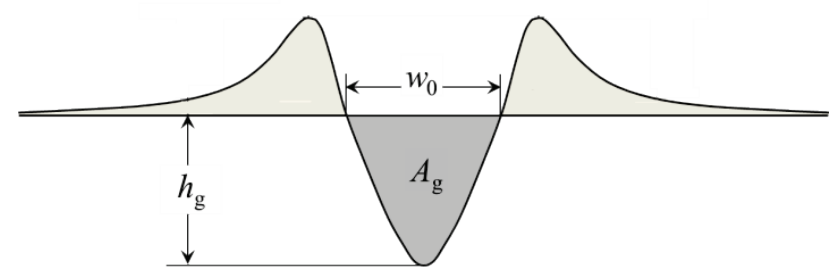

Figure 3 Evaluated dimensions of the groove profile

\section{Results and discussion 3.1 Overview}

The results of the engraving trials performed according to the experimental plan are shown in Tab. 2 . There are three results where the groove was not created (set number 6, 9 and 21), as shown in Fig. 4. For the best fitted model we eliminated these sets from the ANOVA analysis, for all three geometrical variables $\left(A_{\mathrm{g}}, h_{\mathrm{g}}\right.$ and $\left.w_{0}\right)$.

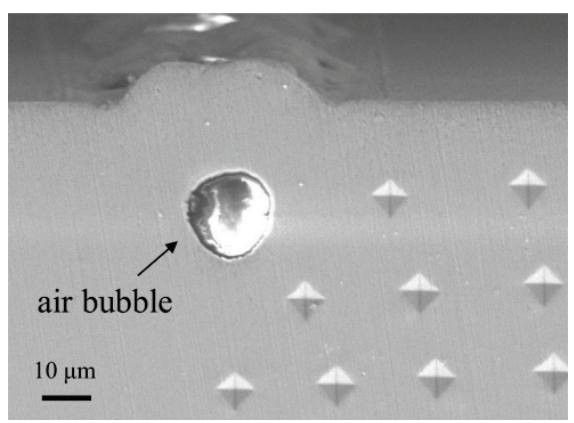

Figure 4 SEM image at the cross-section of a laser-engraved contour with no groove created

Table 2 Design of experiments and corresponding laser-beam engraving

\begin{tabular}{|c|c|c|c|c|c|c|c|}
\hline Set & $\begin{array}{c}f_{\mathrm{p}} \\
(\mathrm{kHz})\end{array}$ & $\begin{array}{c}P \\
(\mathrm{~W})\end{array}$ & $\begin{array}{c}v_{\mathrm{t}} \\
(\mathrm{mm} / \mathrm{s})\end{array}$ & $\begin{array}{c}z \\
(\mu \mathrm{m})\end{array}$ & $\begin{array}{c}A_{\mathrm{g}} \\
\left(\mu \mathrm{m}^{2}\right)\end{array}$ & $\begin{array}{c}h_{\mathrm{g}} \\
(\mu \mathrm{m})\end{array}$ & $\begin{array}{c}w_{0} \\
(\mu \mathrm{m})\end{array}$ \\
\hline 1 & 50 & 10 & 5 & 0 & 140 & 4,7 & 51 \\
\hline 2 & 50 & 10 & 15 & 1 & 5 & 0,3 & 35 \\
\hline 3 & 50 & 10 & 30 & 2 & 0 & 0,0 & 15 \\
\hline 4 & 50 & 12 & 5 & 1 & 167 & 3,7 & 76 \\
\hline 5 & 50 & 12 & 15 & 2 & 13 & 0,8 & 0 \\
\hline $6^{*}$ & 50 & 12 & 30 & 0 & 0 & 0,0 & 0 \\
\hline 7 & 50 & 15 & 5 & 2 & 202 & 3,8 & 97 \\
\hline 8 & 50 & 15 & 15 & 0 & 11 & 1,5 & 20 \\
\hline $9^{*}$ & 50 & 15 & 30 & 1 & 0 & 0,0 & 0 \\
\hline 10 & 100 & 10 & 5 & 0 & 119 & 3,9 & 53 \\
\hline 11 & 100 & 10 & 15 & 1 & 0 & 0,0 & 22 \\
\hline 12 & 100 & 10 & 30 & 2 & 0 & 0,0 & 10 \\
\hline 13 & 100 & 12 & 5 & 1 & 148 & 4,4 & 65 \\
\hline 14 & 100 & 12 & 15 & 2 & 8 & 0,9 & 37 \\
\hline 15 & 100 & 12 & 30 & 0 & 5 & 0,6 & 44 \\
\hline 16 & 100 & 15 & 5 & 2 & 168 & 3,9 & 80 \\
\hline 17 & 100 & 15 & 15 & 0 & 15 & 1,9 & 18 \\
\hline 18 & 100 & 15 & 30 & 1 & 2 & 0,3 & 29 \\
\hline 19 & 150 & 10 & 5 & 0 & 116 & 3,9 & 54 \\
\hline 20 & 150 & 10 & 15 & 1 & 2 & 0,3 & 22 \\
\hline $21^{*}$ & 150 & 10 & 30 & 2 & 0 & 0,0 & 0 \\
\hline 22 & 150 & 12 & 5 & 1 & 119 & 3,9 & 62 \\
\hline 23 & 150 & 12 & 15 & 2 & 7 & 0,6 & 32 \\
\hline 24 & 150 & 12 & 30 & 0 & 0 & 0,0 & 31 \\
\hline 25 & 150 & 15 & 5 & 2 & 132 & 4,3 & 68 \\
\hline 26 & 150 & 15 & 15 & 0 & 38 & 3,9 & 29 \\
\hline 27 & 150 & 15 & 30 & 1 & 0 & 0,1 & 23 \\
\hline
\end{tabular}

("excluded from analysis)

The evaluated results were put into the Design Expert software for further analysis. We needed to find an appropriate model, which has to be a trade-off between a desirable high correlation coefficient and a small number of model parameters. We found that the quadratic model fits best to these requirements, and so it was used for all subsequent analyses. 
The analysis was carried out at the $10 \%$ significance level and at the $95 \%$ confidence level. The backwardelimination procedure was selected to automatically reduce the insignificant terms. The second-order polynomial model equations were formulated for all the variables tested. The following sections contain the results of the ANOVA analysis for each variable. A summary of the results is given in Tab. 3 .

Table 3 ANOVA table results of significance and term contribution for the evaluated variables

\begin{tabular}{|c|c|c|c|}
\hline \multirow{2}{*}{ Source } & $A_{\mathrm{g}}$ & $h_{\mathrm{g}}$ & $w_{0}$ \\
\hline & \multicolumn{3}{|c|}{ Percentage of contribution (\%) } \\
\hline$f_{\mathrm{p}}$ & - & - & 9 \\
\hline$P$ & 3 & 9 & 2 \\
\hline$v_{\mathrm{t}}$ & 69 & 74 & 51 \\
\hline$z$ & - & 4 & 2 \\
\hline$f_{\mathrm{p}} \cdot P$ & - & - & - \\
\hline$f_{\mathrm{p}} \cdot v_{\mathrm{t}}$ & - & - & - \\
\hline$f_{\mathrm{p}} \cdot z$ & - & - & 7 \\
\hline$P \cdot v_{\mathrm{t}}$ & 2 & 2 & - \\
\hline$P \cdot z$ & - & - & 3 \\
\hline$v_{\mathrm{t}} \cdot z$ & - & 2 & 4 \\
\hline$f_{\mathrm{p}}^{2}$ & - & - & - \\
\hline$P^{2}$ & - & - & 4 \\
\hline$v_{\mathrm{t}}^{2}$ & 26 & 9 & 17 \\
\hline \multirow[t]{2}{*}{$z^{2}$} & - & - & - \\
\hline & \multicolumn{3}{|c|}{ Statistical data } \\
\hline$R^{2}$ & 0,957 & 0,943 & 0,978 \\
\hline$R_{\text {adi }}^{2}$ & 0,949 & 0,923 & 0,963 \\
\hline$R_{\text {pred }}^{2}$ & 0,931 & 0,878 & 0,917 \\
\hline$S / N$ & 24,4 & 16,3 & 29,1 \\
\hline
\end{tabular}

The ANOVA for all the geometrical values $\left(A_{\mathrm{g}}, h_{\mathrm{g}}, w_{0}\right)$ shows that the models are significant. The values of $R^{2}$ for these values show that the models explain over $94 \%$ of the total variations. The values of the $R_{\text {adj }}^{2}$ and $R_{\text {pred }}^{2}$ are also high, and both values are in a good agreement (within $5 \%$ ). The parameter levels corresponding to the highest $S / N$ ratios were selected as the optimum parameter level. In this case the $S / N$ ratios $(S / N>10)$ indicate that the models can be used to navigate the design space.

\subsection{ANOVA analysis of the groove cross-section area; $A_{g}$}

The ANOVA analysis for the groove cross-section area $A_{\mathrm{g}}$ shows that the most significant factor affecting the groove cross-section area $A_{\mathrm{g}}$ is the scan speed (a $69 \%$ linear contribution and a $26 \%$ quadratic contribution). The power and the two-level interaction of the power with the scan speed are also significant model factors, but with a much smaller impact. Both interactions contribute around $5 \%$ to the model of $A_{\mathrm{g}}$. The pulse frequency and the focus alone are insignificant factors and were not included in the model. Thus, the second-order model equation for the groove cross-section is given as:

$A_{\mathrm{g}}=82,3+18,0 \cdot P-19,7 \cdot v_{\mathrm{t}}-0,608 \cdot P \cdot v_{\mathrm{t}}+$ $0,577 \cdot v_{\mathrm{t}}^{2}$

After obtaining the model, the effect of the laserengraving parameters on $A_{g}$ was analysed based on the response-surface graphs. Fig. 5 shows a linear relationship for the power and the scan speed on $A_{g}$. It is observed that $A_{g}$ decreases with the scan speed and slightly increases with the power, as expected [12]. A high removal rate can be achieved by increasing the substrate temperature. Using a pulse-laser-beam source this can be done with overlapping laser pulses, so that several consecutive laser pulses irradiate every point on the workpiece surface $[14,21,22]$. It is directly related to the pulse frequency and the scan speed. In our case the overlapping is in the range $97,0 \div 99,8 \%$.

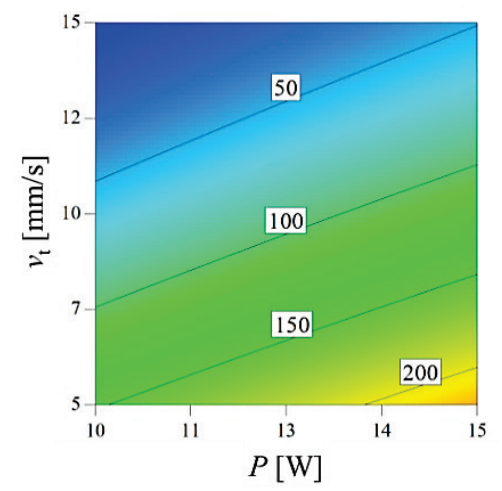

Figure 5 The dependence of the groove cross-section $A_{\mathrm{g}}$ on the power with the scan speed; $\left(f_{\mathrm{p}}=100 \mathrm{kHz}, z=0 \mathrm{~mm}\right)$

\subsection{ANOVA analysis of the groove depth; $h_{\mathrm{g}}$}

The ANOVA results show that the groove depth $h_{\mathrm{g}}$ and the groove cross-section area $A_{\mathrm{g}}$ are highly correlated. Thus the factors affecting the groove depth $h_{\mathrm{g}}$ are similar to the ones for the groove cross-section area $A_{\mathrm{g}}$. The $h_{\mathrm{g}}$ significantly depends on the scan speed (a $74 \%$ linear contribution and a $9 \%$ quadratic contribution) and on the power (a $9 \%$ contribution) as expected $[12,21,22]$. The focus has minor influences on $h_{\mathrm{g}}$ ( $4 \%$ contribution), as well as the two-level interactions of the power with the scan speed $\left(P \cdot v_{\mathrm{t}}\right)$ and the scan speed with the focus $\left(v_{\mathrm{t}} \cdot z\right)$. Both interactions have an around $2 \%$ contribution to the model for $h_{\mathrm{g}}$. The pulse frequency has no influence on $h_{\mathrm{g}}$ at all. These findings are in a good agreement with the studies of Saklakoglu and Kasman [12] and Campanelli et al. [21].

Saklakoglu and Kasman[12] performed the experiments at a much lower pulse frequency $(20-40 \mathrm{kHz})$ and they found that the scan speed and the power have the most important influences on the groove depth, while the pulse frequency has only a minor influence (a less than $0,5 \%$ contribution). Campanelli et al. [21] found that at a higher pulse frequency (around $100 \mathrm{kHz}$ ) the groove depth is almost constant. The overlapping is not an insignificant factor. The maximum depth was achieved at a pulse frequency of $30 \mathrm{kHz}$. In our case the model equation for $h_{\mathrm{g}}$ was given as:

$h_{\mathrm{g}}=0,495+0,605 \cdot P-0,293 \cdot v_{\mathrm{t}}-1,29 \cdot z-$ $0,0158 \cdot P \cdot v_{\mathrm{t}}+0,0425 \cdot v_{\mathrm{t}} \cdot \mathrm{z}+0,00794 \cdot v_{\mathrm{t}}^{2}$

Fig. 6 shows the influence of the scan speed and the focus on $h_{\mathrm{g}}$. The trend lines for the other model interactions of $h_{\mathrm{g}}$ are similar to those for $A_{\mathrm{g}}$. From the presented graph it is obvious that the groove's depth 
decreases with the focus shifting. In this case the focal spot decreases, and so a lower irradiance produces a lower groove depth.

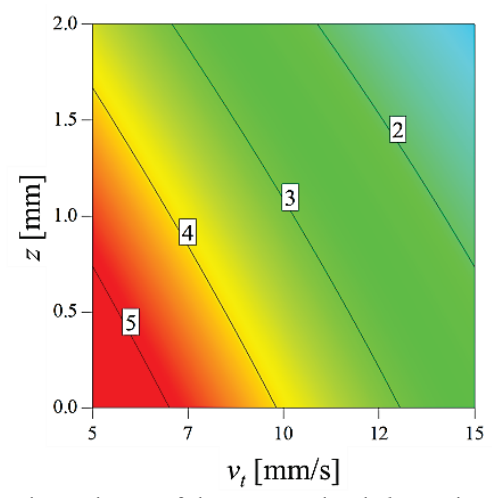

Figure 6 The dependence of the groove depth $h_{\mathrm{g}}$ on the scan speed with the focus; $\left(f_{\mathrm{p}}=100 \mathrm{kHz}, P=13 \mathrm{~W}\right)$

\subsection{ANOVA analysis of the groove width at zero plane; $w_{0}$}

The ANOVA results for the groove width at zero plane $w_{0}$ show that the most significant term effecting $w_{0}$ is the scan speed (a $51 \%$ linear contribution and a $17 \%$ quadratic contribution). The pulse frequency, the power and the focus alone are also a significant factor, but with only a minor influence on $w_{0}$ [23]. The first term contributes $9 \%$ to the model, while the other two terms contribute $2 \%$. The two-level interaction of the pulse frequency with the focus $\left(f_{\mathrm{p}} \cdot z\right)$ (7\% contribution), the scan speed with the focus $\left(v_{\mathrm{t}} \cdot z\right)(4 \%$ contribution) and the square of the power $\left(P^{2}\right)(4 \%$ contribution) are the other terms with secondary influences. The response-surface model for $w_{0}$ is given as:

$w_{0}=-102+0,012 \cdot f_{\mathrm{p}}+29,9 \cdot P$

$-4,58 \cdot v_{\mathrm{t}}-9,16 \cdot z-0,116 \cdot f_{\mathrm{p}} \cdot z+2,77 \cdot P \cdot z-$

$-0,653 \cdot v_{\mathrm{t}} \cdot z-1,24 \cdot P^{2}+0,108 \cdot v_{\mathrm{t}}^{2}$.

Fig.7 presents the nonlinear influence of the factor interactions on $w_{0}$. Fig. 7 a shows the influence of the scan speed and the focus on $w_{0}$. The groove width increases with the focus and decreases with the scan speed.

Fig. $7 \mathrm{~b}$ shows the influence of the pulse frequency and the focus on $w_{0}$. If the focus is on the workpiece surface, the frequency has a negligible influence on the groove width. This is in good agreement with the study of Leone et al. [23]. They performed the experiments at a much lower pulse frequency (under $40 \mathrm{kHz}$ ) and found that the pulse frequency has only a minor influence on the groove width at a lower frequency, while at a higher frequency (above $15 \mathrm{kHz}$ ) there is no influence at all. In our case, if the focus is shifted above the workpiece surface, the groove's width decreases with the frequency. At a higher pulse frequency a thinner groove is performed.

Fig. 7c shows the influence of the power and the scan speed on $w_{0}$. It is obvious that the groove's width increases at a lower power, while at a higher power ( $P$ above 12,5 W) the groove's width decreases. This interaction is more intense at a higher scan speed. a)

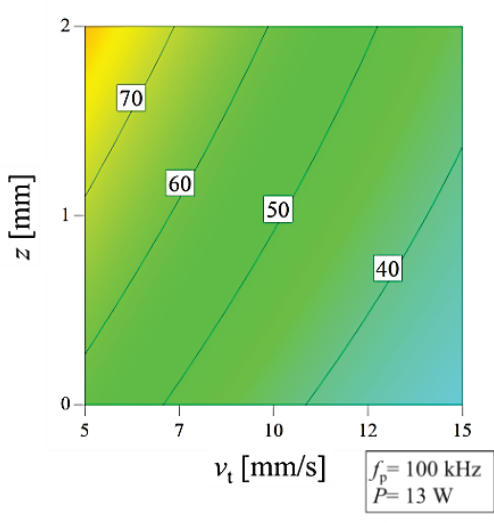

b)

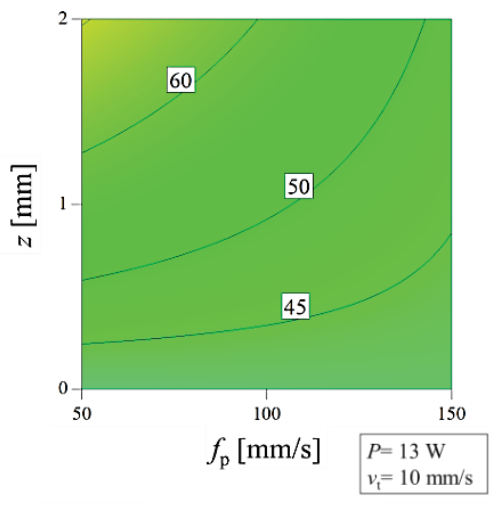

c)

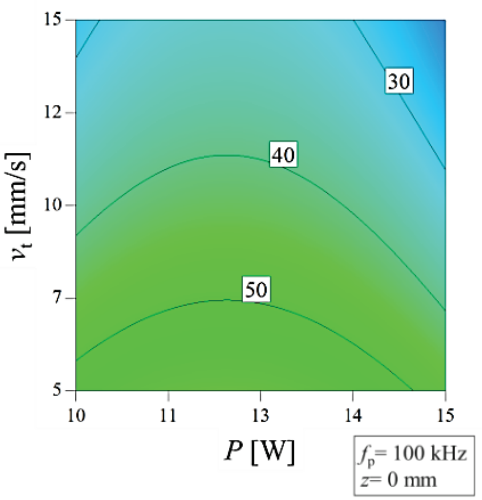

Figure 7 The dependence of the groove width at zero plane $w_{0}$ on: the scan speed with the focus (a),the pulse frequency with the focus (b), and the power with the scan speed (c)

\section{Conclusions}

In this study the influences of the average output laser power, the pulse frequency, the laser-beam scan speed and the focus shift on the engraving process were studied. Using the ANOVA analysis at a $95 \%$ confidence level we evaluated three geometrical variables: the crosssection of the groove, the depth of the groove, and the groove width at zero plane. The ANOVA results of statistical significance evaluated with the $p$-value showed that the models used for all the variables are significant. All the correlation coefficients $\left(R^{2}, R_{\text {adj }}^{2}, R_{\text {pred }}^{2}\right)$ determined with the ANOVA analysis are higher than $87 \%$, which means that the geometrical responses of the variables can be reliably predicted.

We found that:

- The removal rate, the groove depth and the groove width at zero plane are highly influenced by the scan speed. A higher cross-section area, a deeper groove and a wider groove correspond to a lower scan speed 
and a higher power. The power is not as dominant as the scan speed.

In the case of lower power the groove's width increases, while at higher power $(P$ above $12,5 \mathrm{~W})$ the groove's width decreases. This interaction is more intense at a higher scan speed.

- Using a high-quality laser-beam (beam quality parameter $M^{2}$ in the range $1,2 \div 1,8$ ) with a nearly Gaussian transverse mode structure shows that a focus shift in the range of $2 \mathrm{~mm}$ has no influence on the groove's cross-section areas. There is limited impact on the groove depth and the groove width. If the focus is shifted above the workpiece surface, a smaller groove depth and smaller groove width can be obtained.

- If a high laser power source is used a pulse frequency in the range $50 \div 150 \mathrm{kHz}$ has no influence on the groove cross-section and the groove depth, while there is a limited impact on the groove width. If the focus is shifted above the workpiece surface, a smaller groove width can be obtained at a higher pulse frequency.

\section{Acknowledgement}

Operation was part financed by the European Union, European Social Fund. Operation implemented in the framework of the Operational Programme for Human Resources Development for the Period 2007 $\div 2013$, Priority axis 1: Promoting entrepreneurship and adaptability, Main type of activity 1.1.: Experts and researchers for competitive enterprises.

\section{$5 \quad$ References}

[1] Yamamoto, O.; Isomi, A.; Tsukamoto, M. Intaglio printing process and its application. Patent No. US 5201268 A, 1993.

[2] Deinhammer, H.; Loos, F.; Schwarzbach, D.; Fajmann, P. Direct laser engraving of intaglio printing plates. // In Electronic Imaging 2004, (2004, June). International Society for Optics and Photonics, (2004), pp. 184-193.

[3] Šugár, P.; Mikoláš, J.; Šugárová, J. Experimental study of $\mathrm{Nd}$ : YAG laser machining of $\mathrm{Cr}-\mathrm{Ni}$ austenitic stainless steel. // Technical Gazette. 20, 4(2013), pp. 577-580.

[4] Petru, J.; Zlamal, T.; Cep, R.; Monkova, K.; Monka, P. Influence of cutting parameters on heat-affected zone after laser cutting. // Technical Gazette. 20, 2(2013), pp. 225230.

[5] Petronić, S.; Milosavljević, A.; Radaković, Z.; Drobnjak, P.; Grujić, I. Analysis of geometrical characteristics of pulsed Nd: YAG laser drilled holes in superalloy Nimonic 263 sheets. // Technical Gazette. 17, 1(2010), pp. 61-66.

[6] Brousseau, E. B.; Dimov, S. S.; Pham, D. T. Some recent advances in multi-material micro- and nano-manufacturing. // The International Journal of Advanced Manufacturing Technology. 47, 1-4(2010), pp. 161-180. DOI: 10.1007/s00170-009-2499-4

[7] Hebatalrahman, A. The Effect of Laser Parameters on the Surface Characteristic of Irradiated Stainless Steel 304. // Academia Arena. 4, 2(2012), pp. 16-24.

[8] Dubey, A. K.; Yadava, V. Laser beam machining-a review. // International Journal of Machine Tools and Manufacture. 48, 6(2008), pp. 609-628. DOI: 10.1016/j.jimachtools.2007.10.017
[9] Kasman, S.; Saklakoglu, I. E. Determination of process parameters in the laser micromilling application using Taguchi method: A case study for AISI H13 tool steel. // The International Journal of Advanced Manufacturing Technology. 58, 1-4 (2012), pp. 201-209.

[10] Kasman, Ş.; Saklakoğlu, İ. E. Experimental Investigation and Mathematical Modeling of Laser DeepEngraving Process for Microapplication. // Arabian Journal for Science and Engineering. 38, 6(2013), pp. 1539-1549. DOI: 10.1007/s13369-013-0561-x

[11] Sun, Z.; Annergren, I.; Pan, D.; Mai, T. A. Effect of laser surface remelting on the corrosion behavior of commercially pure titanium sheet. // Materials Science and Engineering: A. 345, 1-2(2002), pp. 293-300.

[12] Saklakoglu, I.; Kasman, S. Investigation of micro-milling process parameters for surface roughness and milling depth. // The International Journal of Advanced Manufacturing Technology. 54, 5-8(2011), pp. 567-578. DOl: 10.1007/s00170-010-2953-3

[13] Dabby, F; Un-Chul, P. High-intensity laser-induced vaporization and explosion of solid material. // Quantum Electronics. 8, 2(1972), 106-111.

[14] Dobrev, T.; Dimov, S. S.; Thomas, A. J. Laser milling: modeling crater and surface formation. // Proceedings of the Institution of Mechanical Engineers, Journal of Engineering Manufacture. 220, 11(2006), pp. 1685-1696. DOI: 10.1243/09544062jmes221

[15] Antony, J.; Kaye, M. Analysis and Interpretation of Data from Taguchi Experiments. // In Experimental Quality Springer US, 2000, pp. 151-193.

[16] Chen, Y. H.; Tam, S. C.; Chen, W. L.; Zheng, H. Y. Application of Taguchi method in the optimization of laser micro-engraving of photomasks. // Int J Mater Prod Tec. 11, 3-4(1996.), pp. 333-344.

[17] Kruth, J. P.; Yasa, E. Experimental analysis of process and laser parameters in laser marking. $/ / 9^{\text {th }}$ Biennial ASME 2008 Conference on Engineering Systems Design and Analysis, July 7-9, 2008 (Haifa), American Society of Mechanical Engineers, 2008, pp. 361-371.

[18] Taguchi, G.; Elsayed, E.; Hsiang, T. Quality Engineering in Production System (Vol. 173). McGraw-Hill. New York, 1989.

[19] Design-Expert Software, Version 8, User's Guide, Technical Manual; Stat-Ease Inc., Minneapolis, MN, 2010

[20] Box, G. E. P.; Wilson, K. B. On the experimental attainment of optimal conditions. // Journal of the Royal Statistical Society B. 13, (1951), pp. 1-45.

[21] Campanelli, S. L.; Ludovico, A. D.; Bonserio, C. Experimental analysis of the laser milling process parameters. // Journal of Materials Processing Technology. 191, 1-3(2007), pp. 220-223. DOI: 10.1016/j.jmatprotec.2007.03.005

[22] Wendland, J.; Harrison, P. M.; Henry, M. Deep engraving of metals for the automotive sector using high average power diode pumped solid state lasers. // In Proceedings of ICALEO. 2005.

[23] Leone, C.; Genna, S.; Caprino, G.; De Iorio, I. AISI 304 stainless steel marking by a Q-switched diode pumped Nd:YAG laser. // Journal of Materials Processing Technology. 210, 10(2010), pp. 1297-1303. DOI: 10.1016/j.jmatprotec.2010.03.018

\section{Authors' addresses}

Vladan Mladenovič, M.Sc., Mech. Eng.

Jožef Stefan International Postgraduate School, Jamova 39, 1000 Ljubljana, Slovenia

and 
Cetis d.d.,

Čpova 24, 3000 Celje, Slovenia

and (current):

Plastika Skaza d.o.o.

Selo 20a, 3320 Velenje, Slovenia

E-mail: vladan.mladenovic@skaza.si

Peter Panjan, Ph.D., Research Counsellor

Jožef Stefan Institute,

Jamova 39, 1000 Ljubljana, Slovenia

E-mail: peter.panjan@ijs.si

Srečko Paskvale, Ph.D., Post-doctoral Associate

Jožef Stefan Institute,

Jamova 39, 1000 Ljubljana, Slovenia

E-mail: srecko.paskvale@ijs.si

Halil Çalişkan, Ph.D., Assistant Professor

Bartin University,

Department of Mechanical Engineering,

74100 Bartin, Turkey

E-mail: hcaliskan@bartin.edu.tr

\section{Nastja Poljanšek}

Faculty of Mathematics and Physics University of Ljubljana,

Jadranska ulica 19, 1000 Ljubljana, Slovenia

E-mail: nastja.poljansek@gmail.com

\section{Miha Čekada, Ph.D., Assistant Professor}

Jožef Stefan Institute,

Jamova 39, 1000 Ljubljana, Slovenia

E-mail:miha.cekada@ijs.si 